\title{
THE CHALLENGES OF SUSTAINABILITY IN BUSINESS: HOW GOVERNMENTS MAY ENSURE SUSTAINABILITY FOR OFFSHORE FIRMS
}

\author{
Abul Quasem AL-AMIN ${ }^{\mathrm{a}}$, Walter Leal FILHO ${ }^{\mathrm{b}}$, M. A. KABIR ${ }^{\mathrm{c}}$ \\ anternational Business School, Universiti Teknologi Malaysia, \\ Jalan Semarak 54100 Kuala Lumpur, Malaysia \\ ${ }^{b}$ School of Science and the Environment, \\ Manchester Metropolitan University, Chester str., \\ M1 5GD Manchester, United Kingdom \\ 'Department of Statistics, Jahangirnagar University, Dhaka, Bangladesh
}

Received 31 October 2012; accepted 18 January 2015

\begin{abstract}
This study illustrates some of the challenges of sustainability for businesses and the probable causes of these challenges in relation to Malaysian offshore firms. This study highlights the possible links between business sustainability in the existing types of offshore outsourcing business environments and their failure to transform themselves to adopt best practices. The results of the statistical techniques used to quantify long-term business sustainability indicate that the age of firms has a weak relationship with sustainability and environmental practices $(-0.075)$ and offshore outsourcing issues (0.074). Our study simulations suggest that government support amounting to $5 \%$ of export earnings would ensure offshore investment sustainability in the long term, compared to existing situations. The findings also highlight that this percentage could gradually be increased by $10 \%, 15 \%$ or even $20 \%$, subject to different levels of offshore operations, outsourcing prospects, export earnings, performance and economic development.
\end{abstract}

Keywords: sustainability, offshore outsourcing firms, business environment, corporate social responsibility, environmental practice, Monte Carlo simulations, government, action, policy.

JEL Classification: Q56, M21, C01, O33, O44.

Corresponding author Abul Quasem Al-Amin

E-mail: abulquasem@ibs.utm.my 


\section{Introduction}

The flow of business in offshore outsourcing firms ${ }^{1}$ from the North (i.e. developed countries) to the South (i.e. Asian developing and transitional economies) has brought new business prospects, concerns, opportunities and fourfold economic progress (Krugman et al. 2012; Kakumanu, Portanova 2006; Blinder 2006). Together with the business prospects and opportunities, this flow of business has also brought with it certain demands in relation to fostering sustainable business environments, namely environmental accountability, the diffusion of friendly and cleaner technology, institutional responsibility, ecological compliance and the broader features of corporate social responsibility (CSR) (Berrone et al. 2013; Walls et al. 2012; Babiak, Trendafilova 2011; Azmat, Samaratunge 2009; Baughn et al. 2007; Jones 2005). In particular, there are requirements and new directives that relate primarily to obligatory compliance by foreign-owned and foreign-invested offshore firms in ensuring a sustainable business climate, CSR and environmental responsibility (Babiak, Trendafilova 2011; Dobers, Halme 2009; Jones 2005; Halkos, Evangelinos 2002). Such demands are among the fastest growing concerns of outsourcing businesses in the Asian developing and transitional economies (Antonis et al. 2011; Dobers, Halme 2009; Lindgreen et al. 2009; Rashid, Lodh 2008; Jones 2005; Birch, Moon 2004; Henry et al. 2003; Jaggi, Zhao 1996). Innovations in the field of information technology (IT) over the past three decades and more have been a resource employed by outsourcing business organizations ${ }^{2}$ in developing offshore business prospects and the provision of opportunities in Asian developing and transitional economies, and hereafter will be used to meet the new challenges posed by offshore requirements for sustainability. We therefore turn our attention to the issue of long-term sustainability challenges confronting businesses.

Although certain countries have relevant offshore practices in place to meet the outsourcing requirements and policies on sustainability issues, these are subject to different levels of economic process, institutional views, business execution, business performance, perceptions, implementation and technological diffusion (Aguilera-Caracuel et al. 2013; Aguilera-Caracuel, Ortiz-de-Mandojana 2013; Antonis et al. 2011; Jackson, Apostolakou 2010; Hubbard 2007; Albareda et al. 2007; Bichta 2003; Andrews et al. 1989; Tsang 1998). In particular, these factors vary considerably based on differences in economic values, political and legal systems, capital market responses to environmental policy, proactive environmental strategies, offshore firms' performance and finally levels of economic development (Aragón-Correa et al. 2013; Dahlsrud 2008; Gjolberg 2009; Halkos, Sepetis 2007). According to the literature, issues of sustainability, such as broader CSR, fostering best practice, creating a green business climate, improving environmental performance and the

\footnotetext{
${ }^{1}$ Offshore outsourcing is the practice whereby an external organization performs business in a country other than the one in which the products and services were actually developed or originated. Mainstream theory of why a company operates abroad is usually rooted in financial savings or some derivative thereof.

${ }^{2}$ In this study, we recognize the heterogeneity in the group of outsourcing firms and their relationship with multinational organizations, namely: (a) domestic firms that both import and export related services and are not part of multinational organizations, and (b) offshore outsourcing firms whereby an external organization undertakes business linked with multinational organizations. However, this study focuses on offshore outsourcing firms rather than locally originated multinational organizations.
} 
diffusion of green technology, have traditionally tended to focus on developed countries, where sustainability practices already exist in business operations, business research and business education. In contrast, those sustainability practices (i.e. obligatory offshore firm requirements) are matters of concern in the South and there is currently a paucity of research focusing on developing countries.

The business sustainability concept has been widely applied in organizations in developed countries since the 1970s; unfortunately, though, there has been relatively little focus on developing regions and in Asia (Globerman et al. 2011; Matten, Moon 2008; Birch, Moon 2004; Ramasamy, Woan 2004; Welford 2004). The notions of the sustainable business concept, the sustainable business environment, greener ideas in production, the diffusion of technology, environmental issues and performances, fostering best practice and institutional accountability on the part of foreign-invested offshore firms have spread through foreign direct investment (FDI) inflows in the South (Walls et al. 2012; Belal, Momin 2009; Moon 2008; Jones 2005; Matten, Moon 2004; Welford 2004). Therefore, the demands of offshore business and issues of sustainability represent extra challenges for Asian business in competing with global competitors. This results in the failure of businesses in the South to transform rapidly to ensure compliance and also in many cases failure to overcome the additional challenges by putting the relevant systematic foundations in place.

Bearing these challenges in mind, we have taken the initiative and made one of the goals of our study to investigate the gap between institutional arrangements and business sustainability in Malaysia as it stands, considering the broader sustainable business climate. In addition, we have taken the initiative to explore institutional support as a part of the overall "mandatory" compliance with offshoring requirements through direct government involvement rather than merely relying on legislative guidelines. Equally, institutional theory and stakeholder theory suggest that government intervention is one of the fundamental components in managing offshore compliance by multinational companies and offshore firms, but this is something that is lacking in Malaysia. Therefore, the Malaysian government should take a positive stance towards fostering a broader sustainable business climate and play an important role in shaping business sustainability to attract further offshore outsourcing investment by means of FDI. In addition, to ensure a sustainable offshore business climate, there is a greater need for government involvement in satisfying new offshore roles, responsibilities, shaping offshore vision and strategy, ensuring environmental practice and performance, certifying what qualifies as a workable business environment, setting up applicable targets and allocating resources to be used in achieving them. A further advantage of this involvement is that, by means of peer pressure, other companies will be interested in becoming involved so as not to risk lagging behind others. This is so for three main reasons:

- It encourages companies to ensure that their activities are environmentally sound.

- It promotes a more sustainable business environment.

- It fosters good practice within broader CSR activities.

Thus, our purpose in this study is to further understanding of the challenges to sustainability confronting businesses by going beyond the scope of previous studies, such as those by Rasid, Abdullah (1991) and Chong, Wad (2009), which were limited to describing the 
environmental concerns and CSR of outsourcing firms in Malaysia. In addition, our inquiry addresses the following questions:

(a) What part might government play in assisting businesses to fulfil new offshoring roles and responsibilities in adopting and transforming offshoring requirements?

(b) What might be the government involvement and applicable actions in setting offshore objectives and allocating funds to businesses to work with?

As yet, there is no direct indication of Malaysian offshore outsourcing firms fulfilling offshoring requirements and no concrete outline towards long-term sustainability. It is crucial to analyse what kind of assistance should be provided and to what extent the government should be involved in fulfilling sustainable environmental compliance in the case of Malaysia. Therefore, this study analyses the degree of government involvement subject to different levels of offshore operation, business execution, outsourcing prospects, export earnings and economic development, ${ }^{3}$ as well as the dimensions of performance in IT and electronics firms using numerical simulation scenarios. The simulation scenarios map the institution-driven measures for company-level environmental improvements and address their long-term situations.

\section{Theoretical background/review}

In considering the challenges to sustainability faced by businesses, there are two corresponding theories, namely, institutional theory and stakeholder theory. To overcome such challenges, these two theories are the most applicable for managing corporate sustainability as they relate to the diffusion and adoption of organizational practices among organizations (Baumgartner 2013; Miles 2012; Delmas, Montes-Sancho 2011; Bansal 2005; Kostova, Roth 2002; Lind 2001; Hoffman 1999; Scott 1995; DiMaggio, Powell 1983). Institutional theory highlights the unique institutional complexity faced by multinational corporations (MNCs) and its application highlights prospects as a means of development. It provides opportunities for further development in the dissemination and implementation of organizational measures among organizations, whether these are offshore-based or multinational FDIallied firms (Miles 2012; Westney 1993). The fundamental actions of institutional theory maintain legitimacy and facilitate the adoption of local practices in all business environments to overcome issues in the broader institutional context by considering the intensification of capabilities in relation to internal and external stakeholders (Miles 2012).

In comparison, stakeholder theory argues that organizations should equally involve both internal stakeholders, such as management and employees, and external stakeholders, such as customers, financiers, suppliers, trade associations, political groups, trade unions and governmental bodies, to provide mechanisms that drive best practice in multinational companies (i.e. offshore-based or international FDI-allied firms) and to increase opportunities for the expansion of institutional capacity (Miles 2012). Thus, the fundamental aspects of stakeholder theory may lessen the tension between the demands of offshore requirements for global integration on the one hand and local adaptation in relation to reg-

\footnotetext{
${ }^{3}$ Set by the economic outlook of Malaysia by recent action plans and future national targets (NIP 2004).
} 


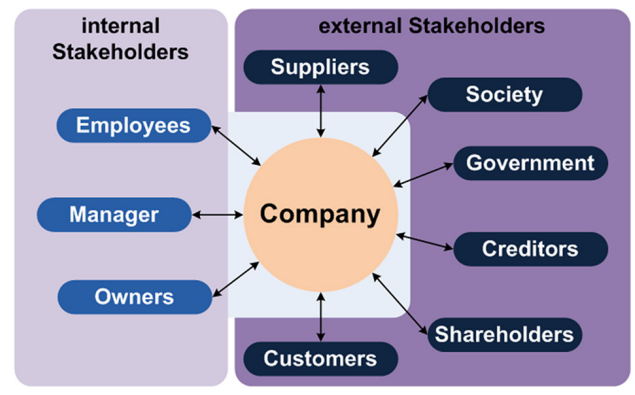

Fig. 1. Internal plus external components of organization by stakeholders' theory Source: Miles (2012).

ulatory compliance on the other (Fig. 1). Rashid, Abdullah (1991) and Chong, Wad (2009) introduced the idea of external stakeholders' intervention in the Malaysian case and also that government should play an important role in shaping environmental practices from a broader CSR perspective, but did not say to what degree or on what basis this should happen. Thus, these studies did not provide mechanisms for driving environmental practices in offshore companies or the expansion of their capabilities.

According to our study, $97 \%$ of offshore outsourcing contracting firms currently receive no direct government assistance for offshore business sustainability. However, government intervention and involvement are fundamental components in both institutional and stakeholder theories to address offshore compliance in offshore and multinational companies. Therefore, we find some gaps in the application of both institutional and stakeholder theories in practice for the diffusion and adoption of organizational measures related to business sustainability and environmental responsibility in Malaysia. There is no doubt that fine-grained support is essential in relation to the mechanisms driving environmental practices in offshore companies. Unfortunately, however, there is as yet no clear indication of offshore firms fulfilling outsourcing requirements as a way forward in ensuring long-term sustainability even it is a key concern; that is, there is no framework. Hence, we propose the adoption of government involvement to lessen the gap in Malaysia in fulfilling new off shoring roles and obligations, ensuring compliance and meeting the challenges presented. In addition, we suggest what role government might play in setting offshore targets and how financial assistance might be allocated. The following two sections concern (i) challenges to sustainability in business - a relative perspective (i.e. problem identification), and (ii) challenges to sustainability in business - a way forward (i.e. gap elimination), thus providing a rationale for the study and supporting the importance of the research questions posed.

\subsection{Challenges to sustainability in business - a relative perspective}

Developing countries with transitional economies are particularly concerned about obligatory requirements for offshore firms because of their lack of ability to adopt and adapt policies quickly and appropriately to provide the relevant technical foundations for a sus- 
tainable business climate (Ortiz-de-Mandojana et al. 2014; Walls et al. 2012; Slawinski 2010; Dobers, Halme 2009; Lindgreen et al. 2009; Birch, Moon 2004). These countries face the need to address issues such as (i) provisions for CSR and promotion of best practice, (ii) provisions for institutional accountability on the topic of sustainable business environments, (iii) provisions for new political and legal systems, (iv) provisions for compliance with environmental requirements based on the economic agenda, (v) commitments to the improvement of the diffusion of green technology (vi) commitments to the improvement of environmental practice and performance, (vii) commitments to the prevention of effluence with an emphasis on source reduction, (viii) commitments to the continuous reduction of environmental risks, (ix) commitments to sharing information on environmental performance with external stakeholders, (x) the ability to further fulfil the environmental agenda beyond the policy guided by the national government, and (xi) the capacity to ensure overall environmental sustainability in business.

We understand that foreign-owned offshore firms are primarily involved in sustainable environmental business practice by complying with the offshoring requirements they are expected to meet (Goitom, Nancy 2008). Hence, complying with these demands is a further challenge for businesses in their bid to compete with other regional opponents. There is no option for offshore outsourcing firms but to comply with the demands for continuous improvement in the relevant sustainability practices and their overall environmental performance. Therefore, some studies view FDI-related outsourcing critically when referring to corporate responsibility, core competences and other related issues in the corporate sector (Guoyou et al. 2013; Tricker 2009; Kakumanu, Portanova 2006; Hayes, Walker 2005; Weidenbaum 2005). The relative impact of offshore firms' inflows is currently a new challenging focus in the business climate (Kazmer 2014; Taylor 2005). Furthermore, subcontracting linkages have also added to concerns with regard to compliance with CSR in a sustainable business climate and the promotion of best practice in business enterprises (Filatotchev et al. 2013; Tricker 2009; Hossain, Reaz 2007; Birch, Moon 2004; Ramasamy, Woan 2004).

In relation to these issues, some studies draw particular attention to Asian regions as the flow of business is shifting from the North to the South driven by turnover and export competitiveness (Badrul 2010). Research examining opportunities and challenges has not been far behind. In particular, the World Bank (2004) addresses the concerns and opportunities in developing countries embedded within the broader aspect of social change in business firms and organizations. Fort (2014) and Hossain, Reaz (2007) examine corporate social reporting, and the determinants, sincerity nexus and characteristics of opportunities and concerns of business organizations in India. Gunawan (2007) addresses corporate social disclosures by companies in Indonesia. Kuasirikun (2005) focuses on attitudes towards business development and the implementation of corporate social reporting related to accountability in Thailand. Zhu et al. (2014) and Gao et al. (2005) study factors concerning corporate social reporting and environmental issues in relation to business organizations in Chinese firms.

Islam et al. (2012), Belal (2007), and Akhtaruddin (2005) address corporate performance, mandatory disclosure practices, opportunities and limitations, corporate perfor- 
mance and the absence of corporate social reporting and corporate disclosures by local and foreign business organizations, respectively, in Bangladesh. Furthermore, Zhu et al. (2014) present a reasonable study of overall corporate social disclosure responsibility and related satisfaction in business organizations in greater detail in the case of Chinese Asian firms. Islam et al. (2012) and Amran, Devi (2007) address the level of corporate social disclosures, sustainable development and corporate social reporting by companies in Malaysia. However, there is a dearth of studies on the possible reasons for the failure by offshore business firms and organizations to meet "mandatory" outsourcing business requirements. There is a fundamental need to establish what, in the long term, is the way forward, as outsourcing business is a matter of concern for the North. These are real issues for developing and transitional counties, Malaysia in particular.

\subsection{Challenges to sustainability in business - a way forward}

According to the literature, a considerable number of studies have recently been conducted focusing on the concept of a sustainable business climate and the promotion of best practice as a broader concern of CSR. These studies have tended to focus on how sustainability practice can be transmitted by means of CSR, focusing "only" on activities and requirements (Aguilera-Caracuel et al. 2013; Walls et al. 2012; Babiak, Trendafilova 2011; Tricker 2009; Goitom, Nancy 2008; Lehman 2007; Lewin, Peeters 2006; Quinteros 2005; Weidenbaum 2005; Wieland 2005; Rossouw 2005; Ryan 2005; Matten, Moon 2004). What then should be the role of developing countries in environmental management aspects? There is a lack of studies on "mandatory" outsourcing business compliance and requirements. Some studies have addressed corporate sustainability through a redefinition of business strategy, eco-design, ecosystem stewardship and eco-efficiency. However, they have not examined outsourcing business requirements and compliance issues imposed by an external organization.

In particular, Kazmer (2014) addresses CSR related manufacturing outsourcing, onshoring, and global equilibrium and environmental integration capacity. Babiak, Trendafilova (2011) addresses management-related environmental best practices and environmental responsibility. Kuo et al. (2012) investigate disclosure of corporate social responsibility and environmental management, environmental policies, sustainable development perception, performance targets, and environmental management systems. Hassan, Ibrahim (2012) addresses corporate environmental information disclosure, efficiency and factors influencing companies' success. Gerdien de Vries et al. (2013) considers how communicated motives for environmental policy affect public perceptions on environmental integrity. Levina, Vaast (2008) address the challenges of environmental performance in promoting best practice. Unfortunately, studies on the challenges confronting businesses in terms of sustainability as an obligatory requirement and linked with government interventions to ensure long-term sustainability, are still lacking for Asia. As far as we are aware, regrettably, no research has been undertaken focusing on offshore business environments and the possible causes of failure to meet offshore compliance. 
Offshore firms are forcing the concept of a sustainable business climate in many developing countries and hence firms are facing intense price competition and market challenges, drawing them further away from existing sustainability practices; Malaysia is no exception in this respect (Weiss 2006). The challenges presented by globalization, such as offshore outsourcing inflows from developed nations, relate to the fact that businesses must always behave according to the standards required by the host countries (Chapple, Moon 2005). Therefore, determining which factors are responsible for attracting offshore inflows is probably the most important aspect of formulating and pursuing a sustainable business strategy. In this context, government action plans for a sustainable business climate, which include ensuring compliance, determining the level of execution, developing implementation procedures and engaging in the diffusion of technology, are crucial as these are the most important factors that should be weighed in determining the expected behaviour of future offshore business.

Malaysia realizes the importance of offshoring for its economic development and efforts in this domain are being harmonized with national interests. While there are exceptions, local firms usually do not have the capability to fulfil a business sustainability agenda beyond the conventional policy guided by the national government. Multinational organizations adopting environmental practices themselves seem to be playing a crucial role in adjusting and transforming their own behaviours, rather than the government. Selected organizations have recently begun trying to incorporate the requirements of offshore legislation as a broader part of CSR whilst fostering a sustainable business climate, but largely do not seem to have established any systematic approach towards integrating business sustainability and performance in line with the standards of the North (Chong, Wad 2009). Hence, the demands of offshore outsourcing on business sustainability and performance are worth analysing in order to identify the gap between institutional arrangements and business sustainability (Aguilera-Caracuel et al. 2013; Tricker 2009; Rossouw 2005; Ryan 2005; Wieland 2005) ${ }^{4}$.

\section{Hypotheses}

In order to develop a clear picture and sound understanding of offshore activities and business prospects in relation to sustainability challenges and the probable causes of these challenges as faced by Malaysian offshore firms, we test several hypotheses. In particular, we aim to find a relationship between challenges to sustainability for offshore businesses and how governments may ensure sustainability in offshore firms. Thus, we propose the following:

$\mathrm{H}_{0}$ : Government involvement does not have a significant effect on sustainability and environmental performance.

$\mathrm{H}_{1}$ : Government involvement has a significant effect on sustainability and environmental performance.

\footnotetext{
${ }^{4}$ However, in developing countries the environmental agenda is different from that in the North. In the North, the challenge is to move beyond existing legislation, whereas in the South it is to make firms comply with legislation (Prieto-Carrón et al. 2006).
} 
$\mathrm{H}_{2}$ : Environmental management and offshore activities are not associated with offshore activities and business prospects.

$\mathrm{H}_{3}$ : Environmental management and offshore activities are associated with offshore activities and business prospects.

\section{Methodology}

\subsection{Survey}

The study used face-to-face interviews to collect data using a structured questionnaire following Chong, Wad (2009).

\subsection{Sampling methods}

Information was collected from over 60 IT and electronics firms out of a total of 70 firms in Malaysia. The data were collected from $2005-2008^{5}$ and eventually encompassed $85.7 \%$ of the total firms, based on ownership, turnover, export competitiveness and size, making the study very representative of the Malaysian context and enabling us to make strong inferences. Concerning offshore sales and figures, the study divided offshore outsourcing into the following categories: most substantial, minor and not considered at all, with respective sales of $67-100 \%, 33-66 \%, 1-32 \%$ and none (0\%) based on the companies' annual figures.

\subsection{Design of the questionnaire}

In order to identify the challenges concerning sustainability and environmental practice in offshore businesses, the study used "sustainable business climate" and "promotion of best practice" questionnaires. Compliance issues and connections between long-term contracts and environmental practices are related directly to conditions governing offshore compliance and legislation. In the South, the goal is to make firms comply with legislation in maintaining obligatory offshore requirements (Prieto-Carrón et al. 2006). Overall, it is important to promote positive attitudes towards a "sustainable business climate" and compliance with the promotion of best practice in the offshore outsourcing market. Consequently, attitudes towards environmental practices, best practice and their importance for a firm's ability to sustain competitiveness in the offshore outsourcing market were charted on a scale of $0-5$ (weakest to strongest).

The importance of the company's customers demanding that the company comply with broader CSR, environmental practice and best practice standards as a pre-qualification in bidding for business was also deemed a vital issue in the questionnaire design. We exam-

\footnotetext{
5 The data were collected from firms throughout Malaysia and it therefore took a period of three years. The data validity and reliability check and pre-test of the questionnaires was performed in accordance with Chong, Wad (2009). We used year 2008-2010 for our study baseline. Hence year as a control variable has already been utilised and thus, the different economic condition to the attribution of data issue from the year 2005-2008 has been avoided.
} 
ined a company's capability to upgrade its overall CSR, environmental practice and best practice standards if required to do so by an important customer and whether the company initiated any best practice upgrading without external pressure. We also considered improvement in business performance upon implementing progressive policies and practices using a five-point Likert scale ( $1=$ no improvement at all, $2=$ not much improvement, $3=$ neutral, neither improvement nor deterioration, $4=$ moderate improvement, $5=$ substantial improvement). In relation to environmental sustainability practices in Malaysian firms, ISO 14000 (ISO 2005) was adopted as an international business standard. Other codes of conduct, such as OHSAS 18001 (BSI 2007), were taken into consideration in contracting firms' offshore compliance with CSR matters. However, companies' adherence to ISO norms is self-reported.

\subsection{Variables used in the model}

A range of variables were used in the different study models as follows: offshore outsourcing, sustainability and environmental practice, foreign ownership, age of the firms, number of employees, health and occupational safety of employees, product technology focusing on environmental quality, process technology focusing on quality, efficiency, product quality, productivity, local and export market shares, corporate image, education/training, and government involvement and assistance. To establish whether stakeholders are affected by the achievement of an offshore firm's objectives, we considered several sub-variables: shareholders, the lead firm (the foreign company from which the outsourcing contract is obtained), employees, customers, suppliers, federal or state government authorities, trade associations, the media, the local community, activist groups and other stakeholders. The models developed concern three types of query: (a) the relationship between environmental practices and offshore outsourcing, (b) the relationship between environmental practices, export markets and subcontracting linkages, and (c) government involvement and assistance towards long-term business sustainability. Hence to attain our research goal, we interrogated different variables (dependent and independent) in relation to these three aspects in our models.

Specifically, to identify the relationship between environmental practices and offshore outsourcing in IT and electronic firms, we used offshore outsourcing as the dependent variable and sustainability and environmental practices as independent variables. In addition, to identify the relationship between environmental practices, export markets and subcontracting linkages with buyers, we used sustainability and environmental practices as dependent variables and offshore outsourcing, foreign ownership, age of firms and number of employees as independent variables. Finally, to examine how governments may ensure sustainability in offshore firms and the comparative outlook of long-term business sustainability and sustainability challenges in offshore firms, we used sustainability and environmental practices as dependent variables and government involvement and assistance as independent variables ${ }^{6}$. The Monte Carlo simulations employed vectors of regression

\footnotetext{
${ }^{6}$ The detailed data collection procedure, questionnaire and sampling design can be found in Chong, Wad (2009).
} 
coefficients and a first order autoregressive process to cover white noise, autoregressive, random walk and explosive processes ${ }^{7}$.

Moreover, we employed a correlation matrix to examine the relationships between variables. The categorical variables and abbreviations are as follows: (a) AGE = number of years the firm has been established, (b) FOWNSH = foreign ownership, (c) NOEMP = number of employees, (d) STMGT = stakeholder management (combination of shareholders/ owners, the lead firm, employees, customers, suppliers, authorities, trade associations, the media, and other stakeholders, (e) SENVP = sustainability and environmental practices (combination of profit margin, sales, cost savings, product price, efficiency, product quality, productivity, market shares, new market, opportunities, corporate image, environmental performance, environmental compliance, reduction of emissions, reduction of solid/liquid waste, recycling, environmental preservation, social performance, health and safety of employees, education/training, staff benefits and non-discrimination, and (f) $\mathrm{OO}=$ offshore outsourcing (labour standards, health and occupational standards, best business practices, ISO 14000 (ISO 2005), OHSAS 18001 (BSI 2007), environmental standards for both practices and relationships with the lead firm(s).

\subsection{Regression technique and Monte Carlo simulations}

In order to fulfil the study goals, two approaches were adopted to identify outcomes. First, the assessment involved using multiple regressions as a statistical approach to observe sustainability challenges; second, Monte Carlo simulations were employed to examine government involvement in fulfilling environmental compliance and long-term sustainability. The data set contained a mixture of categorical and continuous variables. Therefore, advanced techniques were used, rather relying on a simple regression. The Monte Carlo simulation is a computerized mathematical technique that allows users to account for risk in quantitative analysis and decision making. It furnishes the decision-maker with a range of possible outcomes and the probabilities they will occur for any choice of action. It shows the extreme possibilities - the outcomes of going for broke and of the most conservative decision - along with all possible consequences of middle-of-the-road decisions (Kalos, Whitlock 2008). Government involvement in environmental practices is a complex issue which is difficult to measure using traditional methods such as simple regression. Instead, the simulation technique employed here allows the optimum value among the possible solutions to be determined.

\section{Results}

\subsection{Malaysian electronics \& IT firms and their environmental practices}

Of the 60 firms, 52\% adhere to Malaysian environmental regulations and ensure safety, as well as improving their environmental sustainability and CSR and best practice activities (Table 1). According to the study, $90 \%$ of Malaysian IT and electronics firms abide by in-

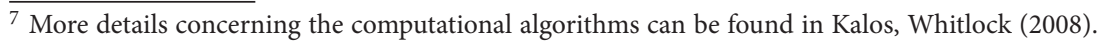


ternational standards such as ISO 9000 (Hoyle 2001). Apart from using ISO 9000 (Hoyle 2001) standards, $67 \%$ of firms practise environmental sustainability in accordance with ISO 14001 (ISO 2005). Other environmental standards, such as OHSAS 18001 (BSI 2007), are followed by $28 \%$ of electronics firms. In our study, we have also identified certain attitudes towards broader CSR and environmental practice. We observed the capability of firms to upgrade CSR, environmental practices and best practice when required by offshore outsourcing companies. We therefore studied whether Malaysian electronics firms initiated any upgrading of CSR, environmental practices and best practice without any external pressure to improve business performance. Our figures show that $67 \%$ of Malaysian firms abide directly by offshore legislation. However, $23 \%$ of these have initiated a CSR and environmental practice out of their own interest. We found that nearly $90 \%$ of Malaysian firms would be able to fulfil environmental sustainability, CSR and best practice requirements if the government were to provide modest additional support within the existing guidelines. According to our findings, $97 \%$ of contracting firms do not receive any support for upgrading CSR, environmental practice and best practice from government or local or non-governmental institutions ${ }^{8}$.

Table 1. Malaysian electronics and IT firms and their environmental practice

\begin{tabular}{|c|c|c|c|}
\hline Issues & Variables & $\begin{array}{c}\text { No. of } \\
\text { Practising Firms }\end{array}$ & $\begin{array}{l}\text { Percentage of } \\
\text { Practising firms }\end{array}$ \\
\hline $\begin{array}{l}\text { Environmental } \\
\text { aspects }\end{array}$ & Environmental regulation & 31 & 52 \\
\hline \multirow{3}{*}{$\begin{array}{l}\text { Environmental } \\
\text { sustainability }\end{array}$} & ISO 14001 & 40 & 67 \\
\hline & OHSAS 18001 & 17 & 28 \\
\hline & ISO 9000 & 54 & 90 \\
\hline \multirow{4}{*}{$\begin{array}{l}\text { Corporate } \\
\text { Social } \\
\text { Responsibility } \\
\text { (CSR) }\end{array}$} & Upgrading on own initiative & 14 & 23 \\
\hline & Upgrading due to demands by firm's suppliers & 40 & 67 \\
\hline & Ability to fully upgrade CSR upgrading & 54 & 90 \\
\hline & $\begin{array}{l}\text { No financial assistance from government/ } \\
\text { non-government institutions }\end{array}$ & 58 & 97 \\
\hline
\end{tabular}

Source: Authors.

Approximately $85 \%$ of electronics firms agreed fully that high-value contracts are obtained due to compliance with environmental practices. Nearly $73 \%$ of the firms' respondents agreed that long-term contracts are awarded due to compliance with environmental quality assurance. Some firms also agreed that improved performance depends on high-value contracts $(82 \%)$ and some also agreed that improved performance depends on long-term contacts $(68 \%)$. There was substantial disagreement concerning the awarding of long-term contracts, with $27 \%$ stating that this depends on compliance with environmental practices. Approximately $18 \%$ of respondents disagreed with the statement that firms perform better due to high-value contracts (Table 2).

\footnotetext{
${ }^{8}$ These firms engage in CSR activities in relation to offshore environmental compliance issues only.
} 
A. Q. Al-Amin et al. The challenges of sustainability in business ...

Table 2. Increases in number of high-value contracts due to compliance with environmental practices

\begin{tabular}{lcccc}
\hline \multicolumn{1}{c}{ Issues } & Agree & Percentage & Disagree & Percentage \\
\hline $\begin{array}{l}\text { High-value contract due to compliance with } \\
\text { environmental practices }\end{array}$ & 51 & 85 & 9 & 15 \\
\hline $\begin{array}{l}\text { Long-term contract due to compliance with } \\
\text { environmental practices }\end{array}$ & 44 & 73 & 16 & 27 \\
\hline Firm performs better due to high-value contract & 49 & 82 & 11 & 18 \\
\hline Firm performs better due to long-term contract & 41 & 68 & 19 & 32 \\
\hline
\end{tabular}

Source: Authors.

We also find that Malaysian electronics firms are experiencing additional expenditure due to compliance with and upgrading of CSR, environmental exercise and best practice, with minor expenses in up to $91 \%$ of cases and substantial expenses in up to $7 \%$. Our study indicates that the benefits to firms may outweigh their expenditure, but in the case of minor expenses this is only true for $4 \%$ of firms, whereas for substantial expenses it is true of up to $57 \%$ of firms. The above results should be an encouragement to improve CSR environmental exercise and best practice activities in Malaysian electronics firms, as well as being encouraging for Malaysian firms which have improved their environmental sustainability, CSR and best practice as a result of offshore requirements (Table 3 ).

Table 3. Annual expenditure on compliance and upgrading

\begin{tabular}{lllll}
\hline \multicolumn{1}{c}{ Issues } & $\begin{array}{c}\text { No expense } \\
\%\end{array}$ & $\begin{array}{c}\text { Minor expense } \\
\%\end{array}$ & $\begin{array}{c}\text { Substantial expense } \\
\%\end{array}$ & \multicolumn{2}{c}{$\begin{array}{c}\text { Extreme expenses } \\
\%\end{array}$} \\
\hline $\begin{array}{l}\text { Annual expenditure on } \\
\text { compliance and upgrading }\end{array}$ & 1 & 91 & 7 & 0 \\
\hline Benefit outweighs expense & - & 4 & 57 & 31 \\
\hline
\end{tabular}

Source: Authors.

Our correlation analyses indicate that age of firms has a weak relationship with sustainability and environmental practices $(-0.075)$ and offshore outsourcing issues (0.074). Hence, we find support for similar research findings and arguments in the related literature in the case of Malaysia. Foreign ownership has a moderate relation with number of employees (0.311). Stakeholder management has a moderately strong relationship with offshore outsourcing (0.371). "Mandatory" compliance with offshore requirements and broader CSR practices show a moderately strong relationship with offshore outsourcing (0.387) which are subject to maintaining long-term contacts (Tables 4 and 5). Therefore, the correlation matrix justifies the need for sustainability challenges in outsourcing business and suggests the probable causes of these challenges in Malaysian offshore firms. In addition, the results of Tables 4 and 5 outline roles for governmental involvement in creating a workable business environment for offshore outsourcing of IT and electronic firms. 
Table 4. Variables used in the study and their correlations with statistical tests

\begin{tabular}{|c|c|c|c|c|c|c|c|}
\hline & riables & AGE & FOWNSH & NOEMP & STMGT & SENVP & $\mathrm{OO}$ \\
\hline \multirow{3}{*}{ AGE } & $\begin{array}{l}\text { Pearson } \\
\text { Correlation }\end{array}$ & 1 & -0.028 & 0.034 & 0.093 & -0.075 & 0.074 \\
\hline & Sig. (2-tailed) & & 0.827 & 0.796 & 0.471 & 0.564 & 0.566 \\
\hline & $\mathrm{N}$ & 62 & 62 & 62 & 62 & 62 & 62 \\
\hline \multirow{3}{*}{ FOWNSH } & $\begin{array}{l}\text { Pearson } \\
\text { Correlation }\end{array}$ & -0.028 & 1 & $0.311^{*}$ & -0.189 & 0.203 & 0.009 \\
\hline & Sig. (2-tailed) & 0.827 & & 0.014 & 0.142 & 0.114 & 0.944 \\
\hline & $\mathrm{N}$ & 62 & 62 & 62 & 62 & 62 & 62 \\
\hline \multirow{3}{*}{ Noemp } & $\begin{array}{l}\text { Pearson } \\
\text { Correlation }\end{array}$ & 0.034 & $0.311^{*}$ & 1 & -0.210 & 0.236 & 0.007 \\
\hline & Sig. (2-tailed) & 0.796 & 0.014 & & 0.101 & 0.064 & 0.958 \\
\hline & $\mathrm{N}$ & 62 & 62 & 62 & 62 & 62 & 62 \\
\hline \multirow{3}{*}{ STMGT } & $\begin{array}{l}\text { Pearson } \\
\text { Correlation }\end{array}$ & 0.093 & -0.189 & -0.210 & 1 & 0.141 & $0.371^{* *}$ \\
\hline & Sig. (2-tailed) & 0.471 & 0.142 & 0.101 & & 0.275 & 0.002 \\
\hline & $\mathrm{N}$ & 62 & 62 & 62 & 70 & 62 & 70 \\
\hline \multirow{3}{*}{ SENVP } & $\begin{array}{l}\text { Pearson } \\
\text { Correlation }\end{array}$ & -0.075 & 0.203 & 0.236 & 0.141 & 1 & $0.387^{* *}$ \\
\hline & Sig. (2-tailed) & 0.564 & 0.114 & 0.064 & 0.275 & & 0.002 \\
\hline & $\mathrm{N}$ & 62 & 62 & 62 & 62 & 62 & 62 \\
\hline \multirow{3}{*}{$\mathrm{OO}$} & $\begin{array}{c}\text { Pearson } \\
\text { Correlation }\end{array}$ & 0.074 & 0.009 & 0.007 & $0.371^{* *}$ & $0.387^{* *}$ & 1 \\
\hline & Sig. (2-tailed) & 0.566 & 0.944 & 0.958 & 0.002 & 0.002 & \\
\hline & $\mathrm{N}$ & 62 & 62 & 62 & 70 & 62 & 70 \\
\hline
\end{tabular}

Notes: ${ }^{*}$. Correlation is significant at the 0.05 level (2-tailed); ${ }^{* *}$. Correlation is significant at the 0.01 level (2-tailed).

Table 5. Variables used in the study and their correlations matrix

\begin{tabular}{ccccccc}
\hline Variables & AGE & FOWNSH & NOEMP & STMGT & SENVP & OO \\
\hline AGE & 1.00 & & & & & \\
\hline FOWNSH & -0.028 & 1.00 & & & & \\
\hline Noemp & 0.034 & $0.311^{\star}$ & 1.00 & & & \\
\hline STMGT & 0.093 & -0.189 & -0.210 & 1.00 & & \\
\hline SENVP & -0.075 & 0.203 & 0.236 & 0.141 & 1.00 & 1.00 \\
\hline OO & 0.074 & 0.009 & 0.007 & $0.371^{* *}$ & $0.387^{* *}$ &
\end{tabular}

Notes: ${ }^{*}$. Correlation is significant at the 0.05 level (2-tailed); ${ }^{* *}$. Correlation is significant at the 0.01 level (2-tailed). 


\subsection{Environmental practices and offshore outsourcing of IT and electronic firms}

To examine the impact of environmental practices and offshore outsourcing of Malaysian firms, we applied a simple model estimated as follows:

$$
\begin{array}{r}
Y=13.5964+8.533 X_{1} \\
(0.0251) \quad(0.0000)
\end{array}
$$

where $Y=$ offshore outsourcing; $X_{1}=$ sustainability and environmental practices (figures in parentheses indicate the $\mathrm{p}$-value); the constant term (13.60) represents average outsourcing; the coefficient is the offshore outsourcing response in relation to the sustainability and environmental practices questionnaire. The $\mathrm{R}^{2}$ value shows that a significant contribution is made to the level of sustainability and environmental practice by $22.25 \%$ of Malaysian offshore outsourcing firms. The model coefficient (8.53), which is positive and statistically significant $(\mathrm{p}$-value $=.000)$, indicates the environmental impact on offshore outsourcing. It is also evident that an increase in sustainability and environmental practice goes hand in hand with offshore outsourcing. For instance, an increase of one percentage point in sustainability and environmental practice corresponds to an increase of 8.53 percentage points in the offshore outsourcing of Malaysian IT and electronics firms.

\subsection{Environmental practices, export markets and subcontracting linkages with buyers}

To assess the many factors which have an effect on sustainability and environmental practices, we used a relatively complex model estimated as follows:

$$
\begin{array}{r}
Y=1.0712+0.0223 X_{1}+0.5279 X_{2}+0.0105 X_{3}+0.0003 X_{4} \\
(0.0214)(0.0001) \quad(0.0406) \quad(0.4813)
\end{array}
$$

where $Y=$ sustainability and environmental practices; $X_{1}=$ offshore outsourcing; $X_{2}=$ foreign ownership; $X_{3}=$ age of firms; $X_{4}=$ number of employees; the constant term (1.07) is average environmental practice; the model coefficients are the environmental responses for the predictors; the figures in parentheses indicate the p-value.

A substantial relationship is found between sustainability and environmental practices and the noted set of predictors, which is certified by the $R^{2}$ coefficient $\left(R^{2}=0.4123\right)$ and model coefficients (all are positive in nature). The offshore outsourcing of contracting firms is the important determinant of their sustainability and environmental practice (the coefficient is highly significant at $\mathrm{p}=0.0001)^{9}$. However, foreign ownership, size of firms, etc., are also significant determinants of environmental practices and in the promotion of a sustainable business climate. The age of the firm in our proposed model is not a significant predictor, but its coefficient is still positive.

\footnotetext{
${ }^{9}$ Environmental performance is the greatest determinant of CSR improvements in Malaysian IT firms.
} 


\subsection{Environmental practices and government involvement}

It is difficult to explore government involvement in environmental practices analytically. We thus applied Monte Carlo simulations to identify possible solutions. In doing so, the finite sample performance of the simulation model is used. Based on zero and alternative hypotheses, the model is employed without and with government involvement as follows: ${ }^{10}$

$$
Y=\beta_{0}+\beta_{1} X_{1}+\varepsilon
$$

\subsection{Monte Carlo simulations}

To examine government involvement, the simulation model is as follows:

$$
\begin{aligned}
& Y_{i}=\beta_{0}+\beta_{1} X_{1}+\beta_{2} X_{2 i}+\varepsilon \\
& i=5 \%, 10 \%, 15 \% \text { and } 20 \%
\end{aligned}
$$

where, $X_{1}$ sustainability and environmental practices; $X_{2}=$ government involvement and assistance; $\varepsilon$ is the residual error and distributed $I N\left(0, \sigma^{2}\right), \beta_{i} ; i=0.1$ are $k \times 1$ vectors of regression coefficients. The $k \times 1$ independent variables are generated from the first order autoregressive process $x_{1 j}=\phi x_{i j-1}+v_{i j}$ with $v_{i j} \approx I N(0,1)$ for $j=0,1, \ldots, n$ where $\phi$ takes the values $0,0.7,1.0$ and 1.02, covering white noise, autoregressive, random walk and explosive processes respectively. The $x_{2 j}$ was generated from uniform distribution with ranges of $0.000-0.050,0.051-0.100,0.110-0.150$ and $0.151-0.200$ to represent up to $5 \%, 10 \%, 15 \%$ and $20 \%$ of government involvement and assistance from export earnings, respectively. We generated 10,000 statistics in a linear regression model for the explanatory variable with a sample size of 60 for four scenarios: (a) government involvement and assistance of less than 5\%; (b) government involvement and assistance of between 5\% and 10\%; (c) government involvement and assistance between 10\% and 15\%; and (d) government involvement and assistance between $15 \%$ and $20 \%$.

Table 6. Summary of results using Monte Carlo simulations

\begin{tabular}{lccccc}
\hline \multicolumn{1}{c}{ Selection Criteria } & $X_{1}$ & $X_{2}(5 \%)$ & $X_{2}(10 \%)$ & $X_{2}(15 \%)$ & $X_{2}(20 \%)$ \\
\hline R-squared & 0.24108 & 0.271085 & 0.241086 & 0.173299 & 0.145398 \\
\hline Adjusted R-squared & 0.22799 & 0.245509 & 0.214457 & 0.156749 & 0.128921 \\
\hline S.E. of regression & 20.8365 & 20.59886 & 21.01846 & 29.98778 & 30.95866 \\
\hline Sum squared resid & 25181.3 & 24185.83 & 25181.22 & 32107.76 & 35038.14 \\
\hline Akaike info criterion & 8.9444 & 8.937055 & 8.977386 & 9.924465 & 9.971688 \\
\hline Schwarz criterion & 9.01387 & 9.041772 & 9.082103 & 9.979182 & 10.076405 \\
\hline F-statistic & 10.4248 & 10.59919 & 9.053650 & 9.863513 & 10.268250 \\
\hline Prob (F-statistic) & 0.00007 & 0.000122 & 0.000385 & 0.000454 & 0.000527 \\
\hline Source: Authors. & & & & &
\end{tabular}

Source: Authors.

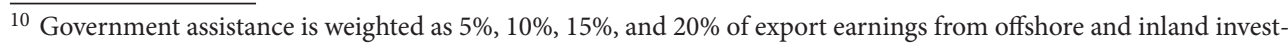
ments.
} 
In the model, error terms were simulated using pseudo random numbers from the GAUSS functions RNDNS, which generate standard normal variations for regression errors. The figure for the random number generator for each experiment was 1,613 . As there are so many ways to develop a performance model, we used the average value of the test statistics. We calculated the average value of model choice statistics by means of a simulation using 10,000 replications with or without governmental involvement and assistance. We found that the statistics depend on the level of direct governmental involvement in the explanatory variables and results (Table 6). The results involve patterns or trends with respect to variations in government involvement.

\section{Discussion}

The literature posits that there is a connection between long-term contracts and compliance with environmental practices. The pressure to comply is derived from the "mandatory" offshore requirements to be maintained for a long-term offshore outsourcing contract (Dobers, Halme 2009; Birch, Moon 2004; Davies 2003). Thus some studies debated on the issues on outsourcing whether onshore or offshore (McCormick 2011). Good governance of environmental practices and broad aspects of CSR is fundamentally accountable for attracting offshore inflows to the South; indeed, it is the most significant factor in terms of being a source of long-term Asian offshore business prospects for outsourcing business organizations from the North (Babiak, Trendafilova 2011; Albino et al. 2009; Ruth et al. 2007). Therefore, it is essential (regarding the environmental aspect) to determine the factors that are responsible for attracting offshore inflows by applying the concepts and notions of both institutional and stakeholder theories. To that end, research is clearly necessary to reduce the challenges of sustainability for businesses and to promote overall best practice in the long-term outsourcing businesses.

Overall, the broad aspects of CSR, environmental practices and sustainability challenges are linked with the integrative framework of business environments, which raises the question of how to adopt best practices at the individual, institutional and organizational levels. The values of the broad aspects of CSR, environmental practices and sustainability challenges and responsibility have commonly framed the processes of stakeholder management, environmental assessment and the outcomes of organizational programmes and policies (Belal, Momin 2009). However, the rethinking of these issues in relation to offshore compliance points to vital research questions that have not yet been addressed in any great depth, particularly in Asian regions. Thus, our concern is to determine the essential challenges faced by the corporate sector and how to ensure sustainability in offshore firms in the $21^{\text {st }}$ century by taking a long-term perspective.

We understand the importance and function of business organizations, shareholders, employees, and competitors and other related challenges in corporate sectors. However, the way in which the respective debates and arguments concerning these different elements are made in the literature is not at all straightforward. There is an increasing body of literature that might support a model towards understanding why developed economies are engaging in broad aspects of CSR, environmental practices and best practice, which are linked with 
the integrative framework of business environments (Aguilera-Caracuel et al. 2013; Ruth et al. 2007). On the other hand, there is an equal output of literature referring to concerns regarding the challenges of sustainability for businesses, such as the pressure to comply with obligatory offshore requirements on the part of transitional economies that depend heavily on offshore-related FDI (Krugman et al. 2012; Dobers, Halme 2009; Birch, Moon 2004).

There is an ongoing debate as to whether business firms are able to cope with the increasing internal and external pressures of broad CSR, environmental practices and best practice issues and the extent to which these may be beyond their ability (Walls et al. 2012; Henderson 2001). Hence, it is essential to know how businesses should be embedded within international offshore compliance parameters and national coordination approaches in relation to different levels of obligatory offshore requirements and local initiatives (Filatotchev et al. 2013; Delmas, Toffel 2012; Dangelico, Pujari 2010; Matten, Crane 2005; Windsor 2004; Davies 2003; Logsdon, Wood 2002; Freeman et al. 2001). Our study bears in mind the scope of the provision for CSR and promotion of best practice, the provision for compliance with environmental requirements based on the national economic agenda, the commitment to improvement of the diffusion of technology, and the commitment to the improvement of environmental performance in the case of Malaysia, as well as concerns regarding these factors. In addition, our study explores the capability of businesses in fulfilling the environmental agenda set by offshore outsourcing beyond policies guided by the national government to ensure overall environmental sustainability in business.

Our study aims to further understanding of the long-term challenges to sustainability in businesses, focusing on (a) environmental practices and offshore outsourcing of IT and electronic firms, (b) environmental compliance, export markets and subcontracting linkages with buyers, and (c) environmental practices and government involvement. In doing so, we consider the hitherto unexplored multilevel theoretical framework of broad CSR, environmental practices and best practice (Guoyou et al. 2013; Slawinski 2010; Waddock et al. 2002). To attain an effective solution, we investigate government involvement and provision of support as key variables in fulfilling new offshore roles and taking responsibility in adapting to offshoring requirements.

We have seen in the introduction that there is a considerable body of literature available on subjects such as (a) organizational performance, (b) firm productivity, (c) individual and organizational responsibility, (d) corporate social performance, (e) stakeholder management, (f) corporate responsibility and outcomes in relation to policies, programmes and social impacts, (g) social changes in firms and organizations, (h) corporate responsibility and organizational embedded in different national systems, (i) corporate responsibility and the narrowing of technical, economic, and legal requirements, (j) traditional economic gains and attachments, (k) CSR, environmental practices and best practice and links with consumers, management, employees, governments and NGOs, (l) corporate governance issues on how to contribute to or collaborate or internalize in good governance, $(\mathrm{m})$ corporate governance and inclusive markets, fair trade, context dependence, (n) illicit money transfers, (o) corporate responsibility and governance choice, and so forth (Delmas, Toffel 2012; Husted et al. 2010; Badrul 2010; Azmat, Samaratunge 2009; Dobers, Halme 2009; 
Lindgreen et al. 2009; Montiel 2008; Baughn et al. 2007; Conley, Williams 2005; Husted 2003).

Yet, there is no direct indication by firms that they fulfil offshore requirements and there is no tangible country-specific speculative structure towards long-term sustainability in Malaysia. In sum, researchers and policy makers are still trying to form the outline of knowledge of CSR, best practice, and links with consumers, management, and employees to fulfil offshore compliance, including that related to environmental issues. Consequently, it is essential to analyse what kind of support should be delivered and to what extent the government should be involved in compliance, as we have done in our study. In particular, we have explored the degree of government involvement and its dimensions for offshore outsourcing compliance in IT and electronics firms, using Monte Carlo simulations with Malaysian firms. We argue that government assistance would ease the challenges for offshore businesses, particularly in terms of environmental performance at the company level, so as to promote overall best practice in the future.

\section{Practical implications}

As already pointed out, in Malaysia there is no indication of the provision of widespread support from the government to offshore firms in fulfilling mandatory requirements towards long-term sustainability. Henceforth, drawing on both institutional and stakeholder theories, we argue the need for government involvement to lessen the gap between requirements and fulfilment and hereafter propose a solution to meet offshoring targets and provide financial assistance subject to different levels of economic development, operation, execution and dimensions using several simulation scenarios. According to our statistical analyses, a notable feature is found in different scenarios: principally, government involvement and assistance amounting to 5\% of export earnings represents the optimal scenario, based on all our selection criteria ${ }^{11}$, under the existing conditions of economic growth, where $\mathrm{R}^{2}$ takes the value 0.2711 ( $\left.\mathrm{SE}=20.5989\right)$. However, when government involvement and assistance is at the $20 \%$ level, $\mathrm{R}^{2}$ takes the value $0.1454(\mathrm{SE}=30.9587)$. Based on the different comparisons, our modelling results show that the $5 \%$ simulated values are preferable in relation to recent figures for Malaysian GDP, export earnings and growth rate.

Researchers and policy makers are trying to establish what kind of assistance should be provided to business in relation to sustainability issues and to what extent the government should be involved. On the basis of our analyses, we recommend that governmental involvement and assistance should be at least 5\% to resolve the challenges to sustainability for offshore outsourcing businesses in Malaysia. At this stage, of the four scenarios developed in this context, a 5\% level of involvement and assistance in offshore outsourcing businesses would work best compared to a $10 \%$ or higher involvement at present; $10 \%$, $15 \%$ or even $20 \%$ levels of involvement and assistance are not currently appropriate given

\footnotetext{
11 The value of the $\mathrm{R}^{2}$, adjusted $\mathrm{R}^{2}$ and $\mathrm{F}$ statistics will be higher for better estimates, and the SE values of the regressions, the sum squared residuals, the Akaike information criteria, the Schwarz criterion and the probability of the F statistic will be lower for the selection criteria.
} 
the existing socio-economic conditions ${ }^{12}$. However, this percentage should be increased gradually in the future, depending on the levels of offshore operations, the development of new outsourcing businesses, increases in offshoring requirements and national economic developments, such as those relating to the GDP situation, export earnings from offshore exports, national per-capita earnings, and eventually higher and sustained national growth rates in Malaysia.

However, it should be considered that this study put into practice and suggestion for the outcomes by adopting a theoretical background. Particularly, this study has been focused on the role of government on offshore firm's sustainability (e.g. hypotheses: H0 and H1), orientation of institutional theory (letting aside stakeholders) to argue by the hypotheses how government influences institutions. However, this study did not consider how the management of the institution itself improved further alone by institutional or stakeholders' theory. Thus future study is required to find the additional hypothesis to uphold the comprehensible arguments for the managers and managements (i.e. institutional) into the institution apart from direct help from the government.

\section{Conclusions}

This study has investigated challenges to sustainability in businesses, such as pressure to comply with CSR, environmental practices, implement improved environmental performance, create a sustainable business climate and promote best practice in foreign-owned and foreign-invested offshore firms. We observe that more than half of Malaysian offshore (IT and electronics) firms are involved in broader corporate social practice in compliance with offshoring requirements. According to our study, more than $70 \%$ of firms are directly obliged by offshoring compliance requirements to continue offshore outsourcing of business and $97 \%$ of firms comply with offshoring requirements without any assistance from authorities, such as government agencies. Although we understand that the flow of business from the North to Asia has brought with it new business demands and opportunities in relation to sustained economic development, particularly in Malaysia, recent sustainable business compliance issues, such as CSR, the green agenda in business, environmental accountability, the diffusion of environmentally cleaner technology, institutional responsibility and ecological compliance, have generated considerable concern in firms. We understand that foreign-owned offshore firms in Malaysia mostly adhere to the environmentally sustainable business practices to which they are subject. However, compliance with these requirements poses additional challenges for Malaysian businesses in their efforts to compete with other global competitors, particularly those from China.

This seems to indicate the need for some sort of government assistance in order to ensure the long-term sustainability of businesses. Here, we analysed the significance of government assistance and the extent of Malaysian environmental performance in foreign-owned offshore (IT and electronics) firms. The results derived from this study show

\footnotetext{
12 The socio-economic conditions stated relate to the economic outlook of Malaysia as set out in recent action plans and future targets (NIP 2004).
} 
that government involvement in CSR, environmental practices and best practice is somewhat appealing for further environmental sustainability in relation to various long-term aspects. From the perspective of statistical simulation, it is apparent that government aid and assistance is important for sustainable business practices. This is important for two main reasons: first, it provides companies with financial support which may alleviate pressures on their budget. Second, this sort of support shows government commitment and provides a more favourable environment which may encourage an increasing number of companies to take part. The findings also suggest that good environmental practice has a positive effect on the reputation and income of companies. The results of this study are justified by scientific techniques and deliver an original approach to resolving the dilemma of how to deliver broader CSR, environmental practices and best practice, and contribute towards ensuring environmental sustainability by compliance with offshore outsourcing legislation in the long term. We believe that this study offers a more precise guideline to ensure further environmental sustainability in Malaysia in offshore outsourcing and, inter alia, to foster business sustainability in the long term.

\section{Limitations}

Self-report data can suffer from recall bias and deliberate misreporting. Even though anonymity and confidentiality were assured during the survey, the respondents might have under-reported or over-reported on particular questions. This misreporting could influence the findings. Although many variables were analysed to meet the objective of the study, the exclusion of some other variables might limit the findings and some of the usual suspects may arise in the analyses. Future studies that are qualitative in nature would also be useful in developing a better understanding of the issues explored here.

\section{Acknowledgements}

We would like to express their gratitude to Professor Dr. Rajah Rasiah and Dr. Sabrina Chong, University of Malaya, for the partial use of their survey data. We sincerely thank the anonymous reviewers for their insightful opinions and suggestions.

\section{References}

Aguilera-Caracuel, J.; Hurtado-Torres, N. E.; Aragón-Correa, J. A.; Rugman, A. M. 2013. Differentiated effects of formal and informal institutional distance between countries on the environmental performance of multinational enterprises, Journal of Business Research 66(2): 2657-2665. http://dx.doi.org/10.1016/j.jbusres.2013.04.002

Aguilera-Caracuel, J.; Ortiz-de-Mandojana, N. 2013. Green innovation and financial performance: an institutional approach, Organization \& Environment 26(4): 365-385.

http://dx.doi.org/10.1177/1086026613507931

Akhtaruddin, M. 2005. Corporate mandatory disclosure practices in Bangladesh, The International Journal of Accounting 40(4): 399-422. http://dx.doi.org/10.1016/j.intacc.2005.09.007 
Albareda, L.; Lozano, J. M.; Ysa, T. 2007. Public policies on corporate social responsibility: the role of governments in Europe, Journal of Business Ethics 74(4): 391-407.

http://dx.doi.org/10.1007/s10551-007-9514-1

Albino, V.; Balice, A.; Dangelico, R. M. 2009. Environmental strategies and green product development: an overview on sustainability-driven companies, Business Strategy and the Environment 18(2): 83-96. http://dx.doi.org/10.1002/bse.638

Amran, A. S.; Devi, S. 2007. Corporate social reporting in Malaysia: an institutional perspective, World Review of Entrepreneurship, Management, and Sustainable Development 3(1): 20-36. http://dx.doi.org/10.1504/WREMSD.2007.012128

Andrews, B. H.; Gul, F. A.; Guthrie, J. E.; Teoh, H. Y. 1989. A note on corporate social disclosure practices in developing countries: the case of Malaysia and Singapore, British Accounting Review 21(4): 371-376. http://dx.doi.org/10.1016/0890-8389(89)90034-6

Antonis, S.; Konstantinos, E.; Ioannis, N.; Walter, L. F. 2011. An overview of corporate social responsibility in Greece: perceptions, developments and barriers to overcome, Business Ethics: A European Review 20(2): 205-226.

Aragón-Correa, J. A.; Martín-Tapia, I.; Hurtado-Torres, N. E. 2013. Proactive environmental strategies and employee inclusion: the positive effects of information sharing and promoting collaboration and the influence of uncertainty, Organization \& Environment 26(2): 139-161. http://dx.doi.org/10.1177/1086026613489034

Azmat, F.; Samaratunge, R. 2009. Responsible entrepreneurship in developing countries: understanding the realities and complexities, Journal of Business Ethics 90(3): 437-452. http://dx.doi.org/10.1007/s10551-009-0054-8

Babiak, K.; Trendafilova, S. 2011. CSR and environmental responsibility: motives and pressures to adopt green management practices, Corporate Social Responsibility and Environmental Management 18(1): 11-24. http://dx.doi.org/10.1002/csr.229

Badrul, H. M. 2010. An overview of corporate social and environmental reporting (CSER) in developing countries, Issues in Social and Environmental Accounting 4(1): 3-17.

Bansal, P. 2005. Evolving sustainably: a longitudinal study of corporate sustainable development, Strategic Management Journal 26(3): 197-218. http://dx.doi.org/10.1002/smj.441

Baughn, C. C.; Bodie, N. L.; McIntosh, J. C. 2007. Corporate social and environmental responsibility in Asian countries and other geographical regions, Corporate Social Responsibility and Environmental Management 14(4): 189-205. http://dx.doi.org/10.1002/csr.160

Baumgartner, R. J. 2013. Managing corporate sustainability and CSR: a conceptual framework combining values, strategies and instruments contributing to sustainable development, Corporate Social Responsibility and Environmental Management 21(5): 258-271. http://dx.doi.org/10.1002/csr.1336

Belal, A. R. 2007. Absence of corporate social reporting (CSR) in Bangladesh: a research note. Proceeding of the research workshop, Aston Business School, UK.

Belal, A. R.; Momin, M. 2009. Corporate social responsibility (CSR) reporting in emerging economies: a review and future direction, Research in Accounting in Emerging Economies 9: 119-143.

Berrone, P.; Fosfuri, A.; Gelabert, L.; Gomez-Mejia, L. R. 2013. Necessity as the mother of 'green' inventions: Institutional pressures and environmental innovations, Strategic Management Journal 34(8): 891-909. http://dx.doi.org/10.1002/smj.2041

Bichta, C. 2003. Corporate socially responsible (CSR) practices in the context of Greek industry, Corporate Social Responsibility and Environmental Management 10(1): 12-24. http://dx.doi.org/10.1002/csr.31

Birch, D.; Moon, J. 2004. CSR in Asia: introduction to the special issue, Journal of Corporate Citizenship 13: 18-23. http://dx.doi.org/10.9774/GLEAF.4700.2004.sp.00004

Blinder, A. 2006. Offshoring: the next industrial revolution?, Foreign Affairs 85(2): 113-128. http://dx.doi.org/10.2307/20031915 
BSI 2007. BS OHSAS 18001 Occupational Health and Safety Systems. Requirements. British Standards, 2007.

Chapple, W.; Moon, J. 2005. Corporate social responsibility (CSR) in Asia, Business and Society 44(4): 415-441. http://dx.doi.org/10.1177/0007650305281658

Chong, S.; Wad, P. 2009. Corporate social responsibility and offshore outsourcing: electrical and electronics firms in Malaysia, International Journal of Institutions and Economics 1(2): 253-282.

Conley, J. M.; Williams, C. A. 2005. Engage, embed and embellish: the theory and practice of corporate social responsibility, Journal of Corporation Law 31(1): 1-38.

Dahlsrud, A. 2008. How corporate social responsibility is defined: an analysis of 37 definitions, Corporate Social Responsibility and Environmental Management 15(1): 1-13.

http://dx.doi.org/10.1002/csr.132

Dangelico, R.; Pujari, D. 2010. Mainstreaming green product innovation: why and how companies integrate environmental sustainability, Journal of Business Ethics 95(3): 471-486.

http://dx.doi.org/10.1007/s10551-010-0434-0

Davies, R. 2003. The business community: social responsibility and corporate values, in J. H. Dunning (Ed.). Making globalization good: the moral challenges of global capitalism. New York: Oxford University Press, 301-319. http://dx.doi.org/10.1093/0199257019.003.0014

Delmas, M. A.; Toffel, M. W. 2012. Institutional pressures and organizational characteristics: implications for environmental strategy, in P. Bansal, A. J. Hoffman (Eds.). The Oxford handbook of business and the environment. New York: Oxford University Press.

Delmas, M.; Montes-Sancho, M. J. 2011. An institutional perspective on the diffusion of international management system standards: the case of the environmental management standard ISO 14001, Business Ethics Quarterly 21(1): 103-132. http://dx.doi.org/10.5840/beq20112115

DiMaggio, P.; Powell, W. 1983. The iron cage revisited: institutional isomorphism and collective rationality in organizational fields, American Sociological Review 48(1): 147-160. http://dx.doi.org/10.2307/2095101

Dobers, P.; Halme, M. 2009. Corporate social responsibility and developing countries, Corporate Social Responsibility and Environmental Management 16(5): 237-249. http://dx.doi.org/10.1002/csr.212

Filatotchev, I.; Jackson, G.; Nakajima, C. 2013. Corporate governance and national institutions: a review and emerging agenda, Asia Pacific Journal of Management 30(4): 965-986. http://dx.doi.org/10.1007/s10490-012-9293-9

Fort, T. L. 2014. The paradox of pharmaceutical CSR: the sincerity nexus, Business Horizons 57(2): 151-160. http://dx.doi.org/10.1016/j.bushor.2013.10.006

Freeman, B.; Pica, M.; Camponovo, C. 2001. A new approach to corporate responsibility: the voluntary principles on security and human rights, Hastings International and Comparative Law Review 24(3): 423-449.

Gao, S. S.; Heravi, S.; Xiao, J. Z. 2005. Determinants of corporate social and environmental reporting in Hong Kong: a research note, Accounting Forum 29(2): 233-242. http://dx.doi.org/10.1016/j.accfor.2005.01.002

Gerdien de Vries; Bart, W. T.; Ellemers N.; Daamen, D. L. D. 2013. Sustainability or profitability? How communicated motives for environmental policy affect public perceptions of corporate greenwashing, Corporate Social Responsibility and Environmental Management (in press). http://dx.doi.org/10.1002/csr.1327

Gjolberg, M. 2009. Measuring the immeasurable? Constructing an index of CSR practices and performance in 20 countries, Scandinavian Journal of Management 25(1): 10-22.

Globerman, S.; Peng, M. W.; Shapiro, D. 2011. Corporate governance and Asian companies, Asia Pacific Journal of Management 28(1): 1-14. http://dx.doi.org/10.1007/s10490-010-9240-6 
Goitom, T.; Nancy, J. B. 2008. Do offshore outsourcing firms in the USA use their investments on corporate social responsibility to alleviate negative attitudes toward offshore outsourcing?, Social Responsibility Journal 4(4): 428-438. http://dx.doi.org/10.1108/17471110810909849

Gunawan, J. 2007. Corporate social disclosures by Indonesian listed companies: a pilot study, Social Responsibility Journal 3(3): 26-34. http://dx.doi.org/10.1108/17471110710835554

Guoyou, Q.; Saixing, Z.; Chiming, T.; Haitao, Y.; Hailiang, Z. 2013. Stakeholders' influences on corporate green innovation strategy: a case study of manufacturing firms in China, Corporate Social Responsibility and Environmental Management 20: 1-14. http://dx.doi.org/10.1002/csr.283

Halkos, G. E.; Evangelinos, K. I. 2002. Determinants of environmental management systems standards implementation: evidence from Greek industry, Business Strategy and the Environment 11(6): 360-375. http://dx.doi.org/10.1002/bse.341

Halkos, G.; Sepetis, A. 2007. Can capital markets respond to environmental policy of firms? Evidence from Greece, Ecological Economics 63(2-3): 578-587. http://dx.doi.org/10.1016/j.ecolecon.2006.12.015

Hassan, A.; Ibrahim, E. 2012. Corporate environmental information disclosure: factors influencing companies' success in attaining environmental awards, Corporate Social Responsibility and Environmental Management 19(1): 32-46. http://dx.doi.org/10.1002/csr.278

Hayes, B.; Walker, B. 2005. Corporate responsibility or core competence, Development in Practice 15(34): 405-412. http://dx.doi.org/10.1080/09614520500075748

Henderson, 2001. Misguided virtue-CSR theory: an empirical test of its main philosophic and economic argument: Bachelor thesis. Amsterdam Fashion Institute International Fashion and Management, Amsterdam.

Henry, C.; Frances, H.; Claire, L. 2003. Developing a coherent enterprise support policy: a new challenge for governments, Environment and Planning C: Government and Policy 21(1): 3-19. http://dx.doi.org/10.1068/c0220

Hoffman, A. J. 1999. Institutional evolution and change: environmentalism and the US chemical industry, Academy of Management Journal 42(4): 351-371. http://dx.doi.org/10.2307/257008

Hoyle, D. 2001. ISO 9000: Quality systems handbook. 4th ed., revised in response to ISO 9000:2000. Butterworth-Heinemann, Linacre House, Oxford.

Hossain, M.; Reaz, M. 2007. The determinants and characteristics of voluntary disclosure by Indian banking companies, Corporate Social Responsibility and Environmental Management 14(5): 274288. http://dx.doi.org/10.1002/csr.154

Hubbard, D. 2007. How to measure anything: finding the value of intangibles in Business. Oxford, UK: John Wiley \& Sons Inc.

Husted, W. B. 2003. Governance choices for corporate social responsibility: to contribute, collaborate or internalize, Long Range Planning 36(5): 481-498. http://dx.doi.org/10.1016/S0024-6301(03)00115-8

Husted, W. B.; Allen, D. B.; Rivera, J. E. 2010. Governance choice for strategic corporate, social responsibility: evidence from Central America, Business \& Society 49(2): 201-215. http://dx.doi.org/10.1177/0007650308315504

Islam, Z. M.; Ahmed, S. U.; Hasan, I. 2012. Corporate social responsibility and financial performance linkage: evidence from the banking sector of Bangladesh, Journal of Organizational Management 1(1): $14-21$.

ISO. 2005. The ISO survey of ISO 9000 and ISO 14000 certificates. Geneva: International Standard Organization.

Jackson, J.; Apostolakou, A. 2010. Corporate social responsibility in Western Europe: an institutional mirror or substitute, Journal of Business Ethics 94(3): 371-394.

http://dx.doi.org/10.1007/s10551-009-0269-8 
Jaggi, B.; Zhao, R. 1996. Environmental performance and reporting: perceptions of managers and accounting professionals in Hong Kong, The International Journal of Accounting 31(3): 333-346. http://dx.doi.org/10.1016/S0020-7063(96)90023-0

Jones, M. T. 2005. The transnational corporation, corporate social responsibility and the outsourcing debate, Journal of American Academy of Business 6(2): 91-97.

Kakumanu, P.; Portanova, A. 2006. Outsourcing: its benefits, drawbacks and other related issues, Journal of American Academy of Business 9(2): 1-7.

Kalos, M. H.; Whitlock, P. A. 2008. Monte Carlo methods. Wiley-VCH, Wiley Publisher. http://dx.doi.org/10.1002/9783527626212

Kazmer, O. D. 2014. Manufacturing outsourcing, onshoring, and global equilibrium, Business Horizons 57(4): 463-472. http://dx.doi.org/10.1016/j.bushor.2014.03.005

Kostova, T.; Roth, K. 2002. Adoption of an organizational practice by subsidiaries of Multinational corporations: institutional and relational effects, Academy of Management Journal 45(1): 215-233. http://dx.doi.org/10.2307/3069293

Krugman, P.; Obtsfeld, M.; Melitz, M. 2012. East Asia: success and crisis, in International economics: theory and policy. Addison-Wesley.

Kuasirikun, N. 2005. Attitudes to the development and implementation of social and environmental accounting in Thailand, Critical Perspectives on Accounting 16(8): 1035-1057.

http://dx.doi.org/10.1016/j.cpa.2004.02.004

Kuo, L.; Yeh, C.; Yu, H. 2012. Disclosure of corporate social responsibility and environmental management: evidence from China, Corporate Social Responsibility and Environmental Management 19(5): 273-287. http://dx.doi.org/10.1002/csr.274

Lehman, G. 2007. A common pitch and the management of corporate relations: interpretation, ethics and managerialism, Journal of Business Ethics 71(2): 161-178. http://dx.doi.org/10.1007/s10551-006-9132-3

Levina, N.; Vaast, E. 2008. Innovating or doing as told Status differences and overlapping boundaries in offshore collaboration, MIS Quarterly 32(2): 307-332. http://dx.doi.org/10.2139/ssrn.1136880

Lewin, A. Y.; Peeters, C. 2006. Offshoring work: business hype or the onset of fundamental transformation, Long Range Planning 39: 221-239. http://dx.doi.org/10.1016/j.lrp.2006.07.009

Lind, E. A. 2001. Fairness heuristic theory: justice judgments as pivotal cognitions in organizational relations, in J. Greenberg, R. Cropanzano (Eds.). Advances in organizational justice. Stanford, CA: Stanford University Press, 56-88.

Lindgreen, A.; Swaen, V.; Campbell, T. 2009. Corporate social responsibility practices in developing and transitional countries: Botswana and Malawi, Journal of Business Ethics 90(3): 429-440. http://dx.doi.org/10.1007/s10551-010-0415-3

Logsdon, J.; Wood, D. J. 2002. Business citizenship: from domestic to global level of analysis, Business Ethics Quarterly 12(2): 155-188. http://dx.doi.org/10.2307/3857809

Matten, D.; Crane, A. 2005. Corporate citizenship: toward an extended theoretical conceptualization, Academy of Management Review 30: 166-180. http://dx.doi.org/10.5465/AMR.2005.15281448

Matten, D.; Moon, J. 2004. Implicit and explicit CSR: a conceptual framework for understanding CSR in Europe, in A. Habisch, J. Jonker, M. Wegner, R. Schmidpeter (Eds.). CSR across Europe. Berlin, Germany: Springer-Verlag, 335-356.

Matten, D.; Moon, J. 2008. Implicit and explicit CSR: a conceptual framework for a comparative understanding of corporate social responsibility, Academy of Management Review 33(2): 404-424. http://dx.doi.org/10.5465/AMR.2008.31193458

McCormick, T. 2011. Outsourcing onshore or offshore?, Accountancy 43(2): 20-22.

Miles, S. 2012. Stakeholders: essentially contested or just confused?, Journal of Business Ethics 108(3): 285-298. http://dx.doi.org/10.1007/s10551-011-1090-8 
Montiel, I. 2008. Corporate social responsibility and corporate sustainability: separate pasts, common futures, Organization \& Environment 21(3): 245-269. http://dx.doi.org/10.1177/1086026608321329

NIP. 2004. National integrity plan: reinventing the future through good governance. Prime Minister Department, Putrajaya, Malaysia.

Ortiz-de-Mandojana, N.; Aguilera-Caracuel, J.; Morales-Raya, M. 2014. Corporate governance and environmental sustainability: the moderating role of the national institutional context, Corporate Social Responsibility and Environmental Management (in press). http://dx.doi.org/10.1002/csr.1367

Prieto-Carrón, M.; Lund-thompson, P.; Chan, A.; Muro, A.; Bhusan, C. 2006. Critical perspectives on CSR and development: what we know, what we don't know, and what we need to know, International Affairs 82(3): 977-987. http://dx.doi.org/10.1111/j.1468-2346.2006.00581.x

Quinteros, C. 2005. Corporate responsibility and the US - Central America Free Trade Agreement (CAFTA): are they compatible, Development in Practice 15(3-4): 572-583. http://dx.doi.org/10.1080/09614520500075722

Ramasamy, B.; Woan, H. 2004. A comparative analysis of corporate social responsibility awareness: Malaysia and Singapore, Journal of Corporate Citizenship 13: 109-123. http://dx.doi.org/10.9774/GLEAF.4700.2004.sp.00013

Rashid, A.; Lodh, S. C. 2008. The influence of ownership structures and board practices on corporate social disclosures in Bangladesh, Research in Accounting in Emerging Economies 8: 211-237. http://dx.doi.org/10.1016/S1479-3563(08)08008-0

Rashid, M. Z.; Abdullah, I. 1991. Managers' attitudes towards corporate social responsibility, in Proceedings of Pan Pacific Conference, June 1991, Kuala Lumpur, Malaysia.

Rossouw, G. 2005. Business ethics and corporate governance in Africa, Business \& Society 44(1): $94-$ 106. http://dx.doi.org/10.1177/0007650305274851

Ruth, V. A.; Deborah, E. R.; Cynthia, A. W.; Jyoti, G. 2007. Putting the back in corporate social responsibility: a multilevel theory of social change in organizations, Academy of Management Review 32(3): 836-863. http://dx.doi.org/10.5465/AMR.2007.25275678

Ryan, L. V. 2005. Corporate governance and business ethics in North America, Business \& Society 44(1): 40-73. http://dx.doi.org/10.1177/0007650305274850

Scott, W. R. 1995. Institutions and organizations. London: Sage publications.

Slawinski, N. 2010. Short on time: the role of organizational time orientation in business sustainability. School of Graduate and Postdoctoral Studies, Western University, London, Ontario.

Taylor, T. 2005. In defense of outsourcing, Cato Journal 25(2): 367-377.

Tricker, B. 2009. Corporate governance: principles, policies and practices. New York: Oxford University Press.

Tsang, E. W. K. 1998. A longitudinal study of corporate social reporting in Singapore: the case of the banking, food and beverages and hotel industries, Accounting, Auditing and Accountability Journal 11(5): 624-635. http://dx.doi.org/10.1108/09513579810239873

Waddock, S.; Bodwell, C.; Graves, S. B. 2002. Responsibility: the new business imperative, Academy of Management Executive 16(2): 132-148. http://dx.doi.org/10.5465/AME.2002.7173581

Walls, J. L.; Berrone, P.; Phan, P. H. 2012. Corporate governance and environmental performance: is there really a link?, Strategic Management Journal 33(8): 885-913. http://dx.doi.org/10.1002/smj.1952

Weidenbaum, M. 2005. Outsourcing: pros and cons, Business Horizons 48(4): 311-315. http://dx.doi.org/10.1016/j.bushor.2004.11.001

Weiss, J. W. 2006. Business ethics - a stakeholder and issues management approach. 4th ed. Mason: Thomson Learning Academic. 
Welford, R. 2004. Corporate social responsibility in Europe and Asia: critical elements and best practice, Journal of Corporate Citizenship 13: 31-47. http://dx.doi.org/10.9774/GLEAF.4700.2004.sp.00007

Westney, E. 1993. Institutionalization theory and the multinational corporation, in S. Ghoshal, E. Westney (Eds.). Organization theory and the multinational corporation. New York: St. Martin's Press, 53-75.

Wieland, J. 2005. Corporate governance, values management, and standards: a European perspective, Business \& Society 44: 174-193. http://dx.doi.org/10.1177/0007650305274852

Windsor, D. 2004. Global corporate social responsibility: international regimes and the constellation of corruption, poverty, and violence, in J. Hooker, P. Madsen (Eds.). International corporate responsibility: exploring the issues. Pittsburgh: Carnegie Mellon University Press, 43-67.

World Bank. 2004. Opportunities and obstacles for corporate social responsibility reporting in developing countries. Report prepared by corporate social responsibility practice of the World Bank Group, US.

Zhu, Q. H.; Yin, H.; Liu, J; Lai, K. H. 2014. How is employee perception of organizationa efforts in corporate social responsibility related to their satisfaction and loyalty towards developing harmonious society in Chinese enterprises?, Corporate Social Responsibility and Environmental Management 21(1): 28-40. http://dx.doi.org/10.1002/csr.1302

\section{APPENDIX}

\section{Questions of the survey}

\section{A. Firm Demographics}

1. Name of firm:

2. Number of employees:

3. What are the THREE (3) main products of your firm?

i.

ii.

iii.

4. Is your firm a public listed company?
(a) Yes.
(b) No.

5. Is your firm is an offshore outsourcing company?
(a) Yes.
(b) No.

6. Is your firm is a multinational outsourcing company?
(a) Yes.
(b) No.

7. Is your firm linked with local company?
(a) Yes.
(b) No.

8. What is the ownership structure of your firm?
(a) State owned (100\%).
(b) 100 percent foreign owned. 
(c) 100 percent locally owned.

(d) Joint venture: Local equity: $\%$; Foreign equity: $\%$.

9. How much of the company's total turnover is derived from contract/subcontract sales (products or services made to customers' design)?

(a) $\%$ of the company's total turnover.

(b) The company does not undertake contract or subcontract work.

10. How much of your company's sub-contracting products/services are exported or go to a foreign customer in Malaysia?
(a) Exported: $\%$.
(b) Sold to foreign customers based in Malaysia: $\%$.
(c) Partly exported and partly sold to foreign customers based in Malaysia:
Exported: $\%$.
Foreign customers based in Malaysia: $\%$.
(d) Do not know.

\section{B. Corporate Social Responsibility and Environmental Performance (CSR-ENV)}

1. Do you feel that CSR-ENV is a voluntary undertaking or forced upon the company one way or the other?
(a) Voluntary activity.
(b) Forced upon the company by its customers or competitors.
(c) Forced upon the company by authorities.
(d) Forced upon the company by other stakeholders (the media, NGOs etc).
(e) Otherwise, how:

2. Do you think that the competitiveness of the company can be improved or damaged by CSR-ENV issues?
(a) No, CSR-ENV issues do not affect the company's business.
(b) Yes, competitiveness can be enhanced.
(c) Yes, competitiveness can be damaged.
(d) Do not know.

3. Overall, do you perceive CSR-ENV as a relatively complicated or simple issue for your company to deal with compared to other challenges faced by the company?
(a) Simple issue/challenge.
(b) Complex issue/challenge.
(c) Depends on the specific CSR-ENV issue/challenge.

4. Do you think that there is a strong connection between long-term contracts and compliance with environmental practices?
(a) Yes, what aspect?
(b) No.
(c) Do not know. 


\section{Stakeholder Management}

1. A stakeholder is any group or individual who can affect or is affected by the achievement of a firm's objectives. Who are your company's stakeholders currently? ( You may circle more than one).
(a) Shareholders/owners.
(b) The lead firm (foreign company that your firm obtains outsourcing contract from).
(c) Employees.
(d) Customers.
(e) Suppliers.
(f) Authorities of federal or state government.
(g) Trade associations.
(h) The media.
(i) The local community.
(j) The public in general.
(k) Activist groups.
(l) Other stakeholders, which ones?

2. Please rate your firm's emphasis on the following stakeholders. (Please circle your rating $0-5$, from weakest to the strongest)

\begin{tabular}{lllllll}
\hline Stakeholders & \multicolumn{7}{c}{ Rating } \\
\hline a. Shareholders/owners & 0 & 1 & 2 & 3 & 4 & 5 \\
\hline b. The lead firm & 0 & 1 & 2 & 3 & 4 & 5 \\
\hline c. Employees & 0 & 1 & 2 & 3 & 4 & 5 \\
\hline d. Customers & 0 & 1 & 2 & 3 & 4 & 5 \\
\hline e. Suppliers & 0 & 1 & 2 & 3 & 4 & 5 \\
\hline f. Authorities of federal or state government & 0 & 1 & 2 & 3 & 4 & 5 \\
\hline g. Trade associations & 0 & 1 & 2 & 3 & 4 & 5 \\
\hline h. The media & 0 & 1 & 2 & 3 & 4 & 5 \\
\hline i. The local community & 0 & 1 & 2 & 3 & 4 & 5 \\
\hline j. The public in general & 0 & 1 & 2 & 3 & 4 & 5 \\
\hline k. Activist groups & 0 & 1 & 2 & 3 & 4 & 5 \\
\hline l. Other stakeholders, which one? & 0 & 1 & 2 & 3 & 4 & 5 \\
\hline
\end{tabular}

3. Overall, how will you describe your relations with your main customers?
(a) Short termed and market based.
(b) Long termed and trust based.
(c) In between.
(d) Do not know.

4. Has your firm participated in any government or non-government sponsored CSR-ENV programme during the last 5 years?
(a) Yes, what CSR-ENV programme?
(b) No.
(c) Do not know. 
5. Did your firm receive any government or non-government assistance (direct grants, subsidies) for CSR-ENV over the last 5 years?

(a) Yes, what kind of assistance?

(b) No.

(c) Do not know.

\section{CSR-ENV Standards and Codes of Conduct}

\section{Questions 1-3, please circle your rating (0-5 from weakest to strongest)}

1. Please rate your firm's emphasis on the following labour and environmental activities.

\begin{tabular}{|c|c|c|c|c|c|c|}
\hline Emphasis & \multicolumn{6}{|c|}{ Rating } \\
\hline a. Health and occupational safety of employees & 0 & 1 & 2 & 3 & 4 & 5 \\
\hline b. Process technology harnessing employee feedback on employees safety & 0 & 1 & 2 & 3 & 4 & 5 \\
\hline c. Process technology focusing on quality of emissions & 0 & 1 & 2 & 3 & 4 & 5 \\
\hline d. Product technology focusing on environmental quality & 0 & 1 & 2 & 3 & 4 & 5 \\
\hline $\begin{array}{l}\text { e. Connections and coordination with government environmental organizations } \\
\text { such as the Ministry of Science, Technology and the Environment }\end{array}$ & 0 & 1 & 2 & 3 & 4 & 5 \\
\hline f. Connections and coordination with environmental NGOs such as CETDEM & 0 & 1 & 2 & 3 & 4 & 5 \\
\hline $\begin{array}{l}\text { g. Connections and coordination with government human and labour } \\
\text { organizations such as the Labour Department (Peninsular Malaysia) and } \\
\text { Occupational Safety and Health Department }\end{array}$ & 0 & 1 & 2 & 3 & 4 & 5 \\
\hline h. Connections and coordination with trade unions & 0 & 1 & 2 & 3 & 4 & \\
\hline
\end{tabular}

2. Are the following practices important for your firm's ability to sustain competitiveness in offshore outsourcing market?

\begin{tabular}{lllllll}
\hline Practices & \multicolumn{7}{c}{ Rating } \\
\hline a. Labour standard & 0 & 1 & 2 & 3 & 4 & 5 \\
\hline b. Health and occupational standard & 0 & 1 & 2 & 3 & 4 & 5 \\
\hline c. Environmental standard & 0 & 1 & 2 & 3 & 4 & 5 \\
\hline d. Others, please specify & 0 & 1 & 2 & 3 & 4 & 5 \\
\hline
\end{tabular}

3. Are the following relationships with the lead firm(s) important for sustaining competitiveness in offshore outsourcing market?

\begin{tabular}{lllllll}
\hline Relationships & \multicolumn{7}{c}{ Rating } \\
\hline a. Labour standard & 0 & 1 & 2 & 3 & 4 & 5 \\
\hline b. Health and occupational standard & 0 & 1 & 2 & 3 & 4 & 5 \\
\hline c. Environmental standard & 0 & 1 & 2 & 3 & 4 & 5 \\
\hline d. Others, please specify & 0 & 1 & 2 & 3 & 4 & 5 \\
\hline
\end{tabular}


4. Has the company adopted any national or international business standard?
(a) No national or international standard adopted.
(b) ISO 9000.
(c) ISO 14001.
(d) OHSAS 18001.
(e) Other standards, which:
(f) Do not know.

5. Has any important customer of the company demanded that the company complies with CSR-ENV standard in order to be pre-qualified for a bid or for getting the order?
(a) No.
(b) Yes, which CSR-ENV standard:
(c) Do not know.

6. Has the company ever collaborated or received support from customer to upgrade its CSR standard?
(a) No.
(b) Yes, how (training in-house, training at customer, training outhouse, technical assistance, financial support)?
(c) Do not know.

7. Does the company get support to improve its CSR-ENV standard from other quarter?
(a) No.
(b) Yes, the government and state agencies.
(c) Yes, private domestic fund?
(d) Yes, private foreign source?
(e) Yes, other source, which:

8. Has the company initiated any CSR-ENV upgrading on its own without external pressure?
(a) No.
(b) Yes, how:
(c) Do not know

9. Has the company demanded that its own supplier addresses CSR problem?
(a) No.
(b) Yes, how:
(c) Do not know.

10. Has the company integrated environmental issue in its operational routine?
(a) No.
(b) Yes, environmental targeting, monitoring and/or reporting
(c) Yes, other routine, which:

11. Has your company integrated social issue (for example by having meeting with employees' representatives) in its company routine?
(a) No.
(b) Yes, social targeting, monitoring and/or reporting.
(c) Yes, other routine, which:

12. Does the company plan to improve the CSR profile, organisation and routine in 2009? (a) No. 
(b) Yes, how:

(c) Do not know.

13. Overall, do you assess that your company presently has the capability to upgrade its CSR-ENV standard if demanded by an important customer?
(a) Yes.
(b) No.
(c) Depends on the specific CSR standards in question.
(d) Depends on the specific ENV standards in question.
(e) Do not know.

\section{E. CSR-ENV Practices and Business Performance}

1. Please rate your firm's improvement in business performance achieved in each of the following categories because of implementing progressive CSR-ENV policies and practices. ( $1=$ no improvement at all, $2=$ not much improvement, $3=$ neutral [there is neither improvement nor no improvement], $4=$ moderate improvement, $5=$ substantial improvement)

Please circle your ratings.

\begin{tabular}{llllll}
\hline \multicolumn{5}{c}{ Categories of business performance } & \multicolumn{5}{l}{ Rating } \\
\hline Economic performance & 1 & 2 & 3 & 4 & 5 \\
\hline Profit margin & 1 & 2 & 3 & 4 & 5 \\
\hline Sales & 1 & 2 & 3 & 4 & 5 \\
\hline Cost saving & 1 & 2 & 3 & 4 & 5 \\
\hline Product price & 1 & 2 & 3 & 4 & 5 \\
\hline Efficiency & 1 & 2 & 3 & 4 & 5 \\
\hline Product quality & 1 & 2 & 3 & 4 & 5 \\
\hline Productivity & 1 & 2 & 3 & 4 & 5 \\
\hline Market shares & 1 & 2 & 3 & 4 & 5 \\
\hline New market opportunities & 1 & 2 & 3 & 4 & 5 \\
\hline Corporate image & & & & & \\
\hline Environmental performance & 1 & 2 & 3 & 4 & 5 \\
\hline Environmental compliance & 1 & 2 & 3 & 4 & 5 \\
\hline Reduction of emissions & 1 & 2 & 3 & 4 & 5 \\
\hline Reduction of solid/liquid waste & 1 & 2 & 3 & 4 & 5 \\
\hline Recycling & 1 & 2 & 3 & 4 & 5 \\
\hline Preserve environment & & & & & \\
\hline Social performance & 1 & 2 & 3 & 4 & 5 \\
\hline Health and safety of employees & 1 & 2 & 3 & 4 & 5 \\
\hline Education/training & 1 & 2 & 3 & 4 & 5 \\
\hline Staff benefits & 1 & 2 & 3 & 4 & 5 \\
\hline Non-discrimination & & & 4 & 5 \\
\hline Social commitment & & & & 4 \\
\hline
\end{tabular}


2. How much does your firm spend annually for the compliance and/or upgrading of CSRENV standards?
(a) The firm does not incur any expense on CSR-ENV.
(b) Minor part of the total expenditure $(1 \%-32 \%)$.
(c) A substantial part of the total expenditure $(33 \%-66 \%)$.
(d) Most of the total expenditure $(67 \%-100 \%)$.
(e) Do not know.

3. Do you agree that the benefits derived from the compliance and/or upgrading of CSRENV standards outweigh the expenditure incurred?
(a) Yes, all the time.
(b) Yes, most of the time.
(c) Yes, occasionally.
(d) No.
(e) Do not know.

4. Do you agree with the "sustainable business climate" and "promotion of best practices" that derive benefits by the compliance issue?
(a) Yes, all the time.
(b) Yes, most of the time.
(c) Yes, occasionally.
(d) No.
(e) Do not know

5. Your other related opinion to maintain the CSR-ENV standard and offshore compliance:

(a) Not interested to discusses.

(b) If interested, please specify:

\begin{abstract}
Abul Quasem AL-AMIN, PhD in Economics, is an Associate Professor at International Business School (IBS), Universiti Teknologi Malaysia. He has published more than 50 international publications including several books. His research primarily includes on technology and policy for economic development and sustainability. In the last 12 years, he was associated with research on development and environment in policy modelling using computable general equilibrium approach; data envelop analysis and econometric tools. Beside these, his research interest includes on modelling international trade \& environment, macroeconomic stability, ecological economics, optimal pollution taxation and developing regional climate change related database.

Walter Leal FILHO, PhD is currently Professor at Faculty of Life Sciences, Hamburg University of Applied Sciences, Germany. He has a degree in Biology and a doctorate in environmental science (PhD), having also completed a post-doctorate programme on environmental communication among other qualifications. He teaches on environmental information, education, communication and management issues at various European universities. He has over 20 years of research experience on all aspects of environmental information and education and has a particular interest on the connections between environmental management, sustainability, climate and human behaviour.
\end{abstract}

M. A. KABIR, PhD in statistics, is an Associate Professor at Faculty of Applied Statistics, Jahangirnagar University, Bangladesh. His research includes on policy issues for development and sustainability, with particular interest to child mortality, safe delivery issues in developing countries. He has more than 15 years of experiences on research and management position. Beside these, his research interest includes on econometric modelling, big data among others. 